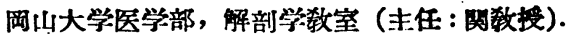

Dept. of Anat., Med. College, Okayama (Director: Prof. M. SEKI).

\title{
硫氣吸入後の線組系の變化。
}

On the changes of the fibrohisticytic system following the inhalation of sulphur gas.

関正次亡板岡一雄 Masaji SEKI a. Käzuo ITAOKA.

(昭和.25年 3 月 3 日原稿受付).

先に関（昭 $17 \mathrm{~b}$, 昭 19）は天然硫黄泉亡硫化カリまたは硫化りーダで作 つた人工硫带泉に動物を入浴せしめ, $\mathrm{H}_{2} \mathrm{~S}$ (硫化水素) と $\mathrm{HS}^{\prime}$ （水硫イオ ン).が浴水に適量あれば浴部のみならす，不浴部の皮下の線組系を刺钱し て多数の線組球や組織球（な單核球）を生ぜしめるが，多量て過ざれば 線組系は中毒して諸細胞功萎縮し, 無力の相貌を示すてとを見た. だが後 の場合にも動物が中毒の時期を凌んで恢復し始めれば, 俄然線組系は活況 を呈し、上述の諸細胞が多数生ずるを常亡する。乙れ等の浴実驗で特に私 共の注意を引んたのは。

1. $\mathrm{H}_{2} \mathrm{~S}$ と $\mathrm{HS}^{\prime}$ の作用が浴部のみならず, 不浴部の皮下に及ふ, 郎ち 身体內に廣く亘るとと,

2. $\mathrm{H}_{2} \mathrm{~S}$ 亡 $\mathrm{HS}^{\prime}$ は線組系を刺戱し, たとへ一時それを中毒させるてと 功あつても，時期を過をれば結局それを刺钱するてと。

その後に板岡 (昭25) が $\mathrm{H}_{2} \mathrm{~S}$ 亿富む草津溫泉水の酸性を中和し, また同. しく $\mathrm{H}_{2} \mathrm{~S}$ に富む四鄉鉱泉水を 2 倍に薄めたものを動物に静注したとてろ, 皮下の線維細胞は先づ萎縮したのち回復して線組球亡組織球になり, 叉は それ等を産生し，その諸細胞に大小の空胞が甚だ多く現れた。

てれ等の实驗から $\mathrm{H}_{2} \mathrm{~S}$ を吸入するも全身の線組系が刺戱せられるてと が想像せられるのであるが, 考虑すべきは, 先づ $\mathrm{H}_{2} \mathrm{~S}$ の溽度である.人 が摆厚な $\mathrm{H}_{2} \mathrm{~S}$ を吸入すれば身体に種ネの変化が起り, 甚だしい場合には 神経中枢の機能が害せられて急死するてとが知られて居る。しかし溫泉場 附近にて少しく臭ふ程度の $\mathrm{H}_{2} \mathrm{~S}$ は人が長年間吸入するも害がなん. 数字 で云う之, 空気中に $\mathrm{H}_{2} \mathrm{~S}$. 加約 $0.01 \%$ 以上あれば数時間で不快な諸症狀加 起り(漂過きれば触れる粘膜飞炎症汃來る)，0.05\%以上あれば失神すると 云ふ..約 $0.0001 \%$ 以下, 郎ち少しく臭ふ程度ならば長時間にも別に症狀 が現れぬ。蓬萊と三井（昭13）は草津の熱の湯の浴場內に $0.000035 \%$ を 見た。. 故に $\mathrm{H}_{2} \mathrm{~S}$ の吸入が治療上に応用せられる亡なれば， $0.0001-0.01 \%$ 
の $\mathrm{H}_{2} \mathrm{~S}$ の暫時または短時反復吸入か, または $0.01 \%$ 以上の $\mathrm{H}_{2} \mathrm{~S}$ の短時 吸入に限るととになる。

$\mathrm{H}_{2} \mathrm{~S}$ の吸入は非結核性の慢性気管支カタルで, 殊に喛嗽亡喀痰の多ん 人に硫黄泉入浴の亡を推獎せられるが，その他の病症にはまだ殆ど経驗せ られていないやうである。私共は大分縣由布院の塚原溫泉に於て, 湯治を 志す結核患者汇地から噴出する硫気の吸入を行はしめる人のあつたのを知 つた。併しその效果は制然しなんらしく，その人は「結核は硫気の吸入た けでは治らない」と云ま。またその人は「古人は猫が硫黄がスに死好之云 つたが、しかし犬も硫黃ガスに弱くして，ガスを数分間吸ふ上醉ひ，後に 死妨とがよくある」と告げた。 犬が吸入した硫黃がスの濃度等を詳かに しないが, 亡まれ犬は人よりも $\mathrm{H}_{2} \mathrm{~S}$ に対し抵抗が弱いのは確からしん。

\section{I. 驗材料と方法}

大分縣由布院の塚原溫泉は别府の背後の湤拔 300 米のところにあり, $\mathrm{pH} 1.6$ の强酸性泉で, $\mathrm{H}_{2} \mathrm{~S}$ 臭加强々. 渚者の一人なる関は別府地方にては この溫泉が最も强く $\mathrm{H}_{2} \mathrm{~S}$ を発散するもの亡見当を立て, その $\mathrm{H}_{2} \mathrm{~S}$ の吸入 実驗を行万目的で, 夏日 20 余頭の二十日鼠を負ひ同地に登つた. 幸にも 附近の山腹飞盛ん飞硫気の噴出するとてろ恓方，その一角に結核患者の 硫気吸入室さへ設けられてあつたから，寒驗動物をててに置いた。因みに $\mathrm{H}_{2} \mathrm{~S}$ の重さは空気の 1.18 倍で, 殆じ等しんから逸散しなん。

箱根湯花沢は海拔 950 米, 溫泉場からやや離れたよころに硫気か噴出す る所があるから，そてで動物実驗を行ふつもりであつたが，ての溫泉水は $\mathrm{pH} 2.4$ で, $\mathrm{H}_{2} \mathrm{~S}$ 臭汃强く, 湧出量劦くして, 權現湯と与衛門湯の合流 する導管のマンホールは好個の $\mathrm{H}_{2} \mathrm{~S}$ 吸入室となつて居たので, こてで泉 水上の $\mathrm{N}_{2} \mathrm{~S}$ の吸入実驗を行つたのである.

塚原でも湯花沢でも吸入室の硫気の臭加强く、 $\mathrm{H}_{2} \mathrm{~S}$ の濃度は凡そ 0.001 \%亡思はれた（测定を缺く）。吸入 2 時閒で何れにも二十日鼠はやや毛か

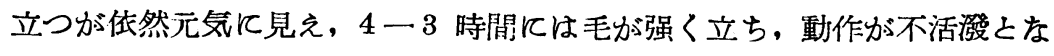
るけれども, 吸入を此めて数時閶後には恢復し, 食慾も殆ど普通となる程 度である.

吸入の 0 日半一6 日後に動物の皮下組織片を取り，37 度に溫められた $0.01 \%$ 中性赤溶液 $(0.9 \% \mathrm{NaCl}$ 溶液で作る) と入れ，15-30 分後に强 㹡大で鏡檢した。 また他方, 組織片を載せガラスに廣げ，乾かなんうちに 1\%オスミウム酸溶液（純水でなく $0.9 \% \mathrm{NaCl}$ 溶液で作る）を滴下し, 5 分ののち $10 \%$ ホルマリンに投じ, 2 日後に鐵へマティン染色を施した. 
ホルマリンだけによる固定でも通例差支なんのであるが，多少胞形質の韭 弱の部分が溶出し海綿樣構造の残るが如さ観があり, 豫めオスミウム酸で 固定しておくと，胞形質がそれよりもよく保存せられ，空胞も明かであ る.

倘は浴場の湯を汲み出し, 私が前（昭 17 a）に行つたやうに二十日鼠を 竹の筒に入れて身体後部を入浴させた. その湯の $\mathrm{pH}$ は塚原で 1.6 , 湯花 沢で 2.4, $\mathrm{H}_{2} \mathrm{~S}$ 臭の强さは湧出直後のものに比して著しく減じてねた.

確実のため各実驗に動物が $2-3$ 頭づつ用ひられた。

\section{II. 寞 驗 結 果}

硫気吸入の線組系への作用の記載の前に述べたんのは，その身体への障 害の栄外少んてとである. 数年前私が二十日鼠で强酸性泉浴の実驗を行つ たとき，岡山に取寄せた湯花沢の弘法湯の $\mathrm{H}_{2} \mathrm{~S}$ 臭加あまり强く、動物加 入浴数分で失神し溺死したのを $\mathrm{H}_{2} \mathrm{~S}$ の中毒のため之考へ，泉水を数時閒 から゙一夜放㯰し， $\mathrm{H}_{2} \mathrm{~S}$ 臭が咸ずるのを待つて実驗を反復したてとがある. hま湯花沢にて二十日鼠で $\mathrm{H}_{2} \mathrm{~S}$ 吸入実驗を行ま傍ら，人の入る浴室で $\mathrm{H}_{2} \mathrm{~S}$ 臭の少くなつた $\mathrm{pH} 2.4$ の泉水を汲出し，動物の身体後部を入浴させたと とろ, 3 頭のうち 1 頭は速かに弱つて入浴 15 分で死し, 他の 2 頭 入浴 30 分後, 毛を立て, 元気少く，走り得存かつた。 ての結果から見ると, 動 物を中毒させた主なものは $\mathrm{H}_{2} \mathrm{~S}$ でなく，泉水の强酸性である．人が垚を 開放した同浴室に約 1 時閒止り，その閶度々入浴してみる之頭痛や惡心を 起すと亡がままあるのも泉水の强酸性によるに違ひなん. 但し石原 (昭22) は湯花沢溫泉に 1 日 3-4 回, 1 週閒入浴した人の基楚代謝には殆ど変化が なかつたと云よ。

硫気吸入実驗の結果の大体を略語を用ひて表に示す． F は線維細胞型 (線維細胞が全細胞の 70-80\%, 又はそれ以上を占めるもの), FH は線 組球型（線組球亡組織球が最多で，全細胞の 50-60\%を占めるもの), H は組織球型（ビの細胞種よりも組織球が多くして，全細胞の $30-40 \%$, 又はそれ以上を占めるもの), Atr は萎縮型 (細胞が一般に瘦せ, 空胞が小 で, 固定標本では胞形買の染色性が減じ, 特に線維細胞の胞体の輸碍が甚 だ不明瞭なもの)である。もし一の動物で, 例へば或るとてろは F, 或る とてろは FHである場会には $\mathbf{F}, \mathbf{F H}$ 己併記し，去た例へば大㑈は $\mathbf{F H}$ であるけれども，ややHの傾向のある場合には FH(H) Eした。な庄諸、 細胞に空胞が多んとをはVak, やや多んとさは（Vak）を附記した。 
硫気吸入, 硫気吸入之强酸性泉入浴, 强酸性泉入浴の

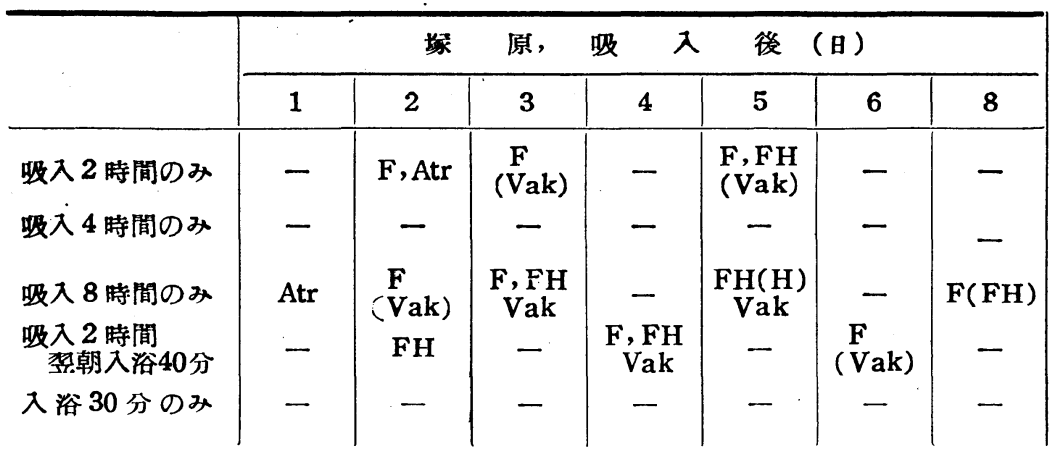

表に次の所見を附言する. Fbc は線維細胞, Fbhsc は線組球, Hsc は組 織球, Mnc は單核球の略字である.

1. 動物が数時閒硫気を吸入し, 中毒して一時動作の.不活潑になる程度 て達する亡，皮下の線組系の諸細胞は萎縮する。しかし萎縮は 1 日までで， 次で線組系はその反応の如くに動員し始め, Fbhsc（Fbc 之Hsc の移行 型）や Hsc（なほ Mnc）功生じ, 約 10 日後に始めてほぼ元の狀態に戻る. かかる線組系の細胞の增滅は從來の藥液の皮膚塗布, 同皮下注射, 細菌注 射等の実驗でも常に認められたてとであるが，てて硫気吸入にて特筆すべ きは，動員期之恢復期の線組系の諸細胞（Fbc，Fbhsc，Hsc）飞現れる大 小の空胞が他の場合に比して多んてとである. 而しててれ之組織の水腫の 有無多少亡には規則的の関係がなん。

2. 硫気吸入後の線組系の変化が便宜上皮下だけにつき観祭せられた が，同樣の変化は当然全身の線組系に起つてみる亡見ねばならぬ。

3. 既に人の知る如く强酸性泉に入浴すれば, 皮下の線組系が强く刺㦸 せられて活動する.だから硫気吸入に次んでかるる入浴を行えば, 少くも 浴部の皮下には線組系の萎縮が現れなん。

4. 因みに血球に関しては, 例を舉げる之, 塚原吸入 3 時閒の 3 日後に 顒動脈の血液飞赤血球 879 万, 白血球 7800 あり, リンパ球 $81 \%$, 單核球 $9 \%$ ，中好性白血球の杆狀核の\&の $1 \%$ ，分節核の\&の $9 \%$ ，孔核の\&の 0\%加見られ，塚原吸入 2 時間，入浴 40 分では吸入の 4 日後に赤血球 753 万, 白血球 6600, リパ球 $67 \%$, 單核球 $10 \%$, 中好性白血球の杆狀核の もの6\%, 分節核の\&の $13 \%$, 孔校の\&の 4 \%で, 要するに入浴のもの に中好性白血球が僅かに增す傾向があつたほかには特記すべことがなか ১た. 
後の皮下線組系の変化

湯花沢, 吸入 (又は入浴) 後 (日)

\begin{tabular}{|c|c|c|c|c|}
\hline 2 & 3 & 4 & 6 & 13 \\
\hline- & - & $\underset{(\text { Vak })}{\mathrm{F}}$ & $\underset{\text { (Vak) }}{\mathrm{FH}}$ & - \\
\hline $\begin{array}{c}F(\text { Atr) } \\
(\text { Vak })\end{array}$ & $\underset{\text { Vak }}{\text { F, FH }}$ & - & $\begin{array}{c}\text { FH } \\
\text { Vak }\end{array}$ & $\underset{(\text { Vak })}{\mathbf{F}}$ \\
\hline- & - & - & - & - \\
\hline- & - & - & - & - \\
\hline F, FH & - & $\begin{array}{l}\text { F, FH } \\
\text { (Vak) }\end{array}$ & - & $\begin{array}{l}\text { F, FH } \\
\text { (Vak) }\end{array}$ \\
\hline
\end{tabular}

次に細胞像を詳細に観祭し たととろを記載する.

1. $\cdot \mathrm{H}_{2} \mathrm{~S}$ 吸入後の線組系の 萎縮期には, 固定標本では諸 細胞の胞体が一般に瘦せ、特 に Fbc の輪厗が不明瞭で, 胞形質の染色性がわるん，中 性赤で超生染するに，Fbcの 空胞は微小で, 数少く，色は 帶黃赤である. また Hsc \& 宾胞怔比較的頚弱で,やはり

赤に黃を帶びるものが多く，細胞の華麗なものか稀である.

2. 吸入の 2-6 日後の線組系の動員期には Fbc K中性赤に不染と染 性の空胞が增し，空胞は大きくなり，Fbc には Fbhsc となり進んで Hsc 飞轉化するものが少くなく，まを往々 Mnc を生ずる(附図参照).よく落 着んて観祭すれば，その他に不染性の 2-3 の大なる空胞（時になほ 3-4 の不染小空胞）を持ち，俘足を出す特型が時々見当り，固定標本にては胞 形質が Fbc のものの性奨を示し，また核は染色質が少くて幼若に見える から，ての細胞は浹して血液から遊出したものでなん。故に私はてれを假 スアメーバ樣 Fbc と呼ふ（附図 amFbc). その核は大なる空胞に匠せられ 陷凹を現すことが甚だ屡ばである．とのフメーバ樣 Fbc は普通の細菌に よる急性炎症にも現れ, またてれて類似の細胞は組織培養のときよく認め られるけれども，從來多くの研究者に見逃され：又は詳しh観祭から除外 せられてんたのが不思議である. このフメーバ樣 Fbc の不染性の空胞は 後に內容が次第に濃くなり, 强く中性赤に染るに至り, 同時に胞体が肥大 して Fbhsc または Hsc に轉化し得るもの之認められた。

3. 諸細胞の空胞の中性赤に不染性のものは队容が薄く, 水樣で, それ によく染るものは內容が濃厚なことは易く想像せられるが，実際强く染つ た空胞には輪噼が不規則に凹凸するものが少くなく，てれと粒子との区別 のつかぬものさへある.

4. 完成した Hsc は胞体が大で, 中性赤に不染の空胞が少く, 濃染の 空胞亡粒子に充され，胞体の外形が常に類球形なとよから祭するに，むは や盛んに物質を攝取蓄皘したり，よく遊動したりし得なんやうである（附 田 Hsc). 空胞のうちで小なるものは多くは帶黄赤, 大なるものはみな赤 であるが，粒子は濃赤に染る．Hsc 類似で不染性亡弱染性の空胞を多く持 
つものは, 胞体が廣り，大小の僞足樣の笑起を示すことが多く，てれは未 完成の Hsc または Fbhsc である.

5. 線組系の動員期を過されば，Hsc の大部分は廣つて Fbhsc 亿戻り， また Fbhsc は Fbc 飞杘り，Mnc は Fbc 样になる。乙の恢復期の Hsc 之 Fbhsc には中性赤空胞の芫だ多んものがあり, 空胞のうちには細胞の 表面から膨出し, 時には, 私共の新しく発見したてとであるが, 表面から 離断せられるものもある (附図). 宾胞は殆んど正しく球形で, フィルム 樣倸足 Film-like pseudo-podia とは違ふ. てれ等の空胞は破裂して內容を 外界に散ずるととは疑いないけれども，破裂の僢閒はまだ見当つてんなん。

$\mathrm{H}_{2} \mathrm{~S}$ \& $\mathrm{HS}^{\prime}$ ＆自ら酸化して他を還元する力が甚だ强いか心，それが生体 內で如何に働くか，詳しんこよはまだ分らなん，それが触媒作用を有する 鐵に結合しててれをてれを硫化鐵となせば，酸化機轉を抑制し細胞を空息 させる結果となるであらう．また Sluiter (1930) 功還元グルタチオンと S から $\mathrm{H}_{2} \mathrm{~S}$ の生市るととを証明したので, $\mathrm{H}_{2} \mathrm{~S}$ 吸入時には細胞內にそれと 逆の

$$
\mathrm{G} \cdot \mathrm{S} \cdot \mathrm{S} \cdot \mathrm{G}+\mathrm{H}_{2} \mathrm{~S} \rightarrow 2 \mathrm{G} \cdot \mathrm{SH}+\mathrm{S}
$$

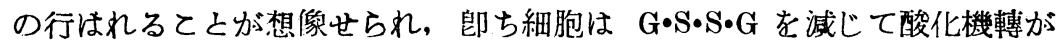
衰へるととになる．実際 Dixon (1934)、は $\mathrm{H}_{2} \mathrm{~S}$ の少量が酵母の呼吸を完 全に止めるを見た。然してれ等の酸化滅衰と線組系の動員や空胞增加亡の 閒にはまだ直接の連籘が見出せなん。

組織学にて腺の分泌の現像は普通の腺にても內分泌腺にても今日までに 甚だよく観祭せられたが, 免疫物質, 郎ち抗原に対する抗体がどてで, ど のやうに産生せられるか，殆ど究明せられてみない，沢近（昭25）は葡萄 狀球菌, 大腸菌, 琶口㾑菌を皮下に入れる亡, それが主に Fbhsc K, 一 部は Fbc と Hsc にも取られ, 取られた菌の周圍に液体が溜り, 菌はその 空胞內で消化せられて行くのを確めた。私共はての実驗之，なほ沢近の組 織抽出液の細菌の発育に质夺作用の実驗（印刷中）から抗体の主產地は 空胞であらう之推定する。果し.て然らば細胞に空胞を多く生ぜしめる $\mathrm{H}_{2} \mathrm{~S}$ または類似のS 含有の化学品を適当に利用するてとにより抗体產生を垻し 得るやうなとよがあるかも知れなん。

\section{III. 結語}

由布院塚原にては地上に噴出する硫気孝, 箱根湯花沢にては泉水上の硫 気を二十日鼠に吃入せしめ，1-13 日後に皮下組織を取り，主として中性 赤で超生染して鏡檢し，また固定して鐵へマテイン染色を施しても観繁し 
た.

1. 多量の硫化水素の吸入によつて線組系の細胞が萎縮するてよがある 加，1 日後はその反動の如くに動員期に入り，中性赤に不染性之染性の空 胞を持つ線組球や組織球 (なほ單核球) が多く生じた.

2. 線維細胞のうちには中性赤に染らぬ大なる空胞を生じ僞足を出すも のが見られ、フメーバ樣線維細胞亡名づけられた。 てれは後に線組球や組 織球に轉化し得る。

3. 恢復期の組織球亡線組球の室胞のうちには細胞の表面から膨出し, 時に離断せられるものがある。空胞は破裂して们容を外界に散ずるとと疑 ひなん.

4, 硫気の吸入は血液細胞の数や種類には格别の変化を残さなん.

5, 私共の從來の実驗によれば線組系細胞の空胞に免疫物質の多く座生 せられるととがほら゙確実である。しからば線組系の細胞に空胞を生ぜしめ るやうと作用する硫化水素や類似の $\mathrm{S}$ 含有の化学品の適当の利用がかく して免疫物質の產生を助長するか, どらか。てれは解決しなければならぬ 問題である。

\section{Authors' abstract.}

Mice were exposed to air above the surface of a volcano or to that above the water of a hot spring which contains hydrogen sulphide. A piece of the subcutaneous tissue was taken out from time to time and stained by neutral red in vitro.

One or two days after inhalation the changes are but little, most fibrocytes being rather atrophied. On the third to the seventh day, however, unstainable and stainable vacuoles inc:ease in number and size in the fibrocytes and fibrohistiocytes. The unstainable vacuoles of the. fibrocytes often expand considerably. Enlarged cells showing the accumulation of red vacuoles and granules are nothing but histiocytes. Some vacuoles swell out from the surface of the cells and can be separated from them. Probably these vacuoles are to be broken and to throw off their contents into the surrounding medium, but an instance of this phenomenon has not yet been caught by us. On the fifth to tenth day the majority of the hisitocytes begin to spread their bodies, turn then into fibrohistiocytes and in the end return to fibrocytes. 


\section{文献}

Dixon, M : Respiratory inhibitors. Arch. exp. Zellforsch. 15 (1934). 一 石原示 壦：入湯後の基礎代謝の交動. 日溫気誌. 12 (昭22). 一板岡一雄: 溫泉水の静注が

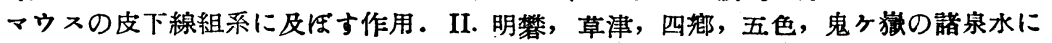
よる実驗. 日組錄. 1 (昭25)。一落萊信男と三井羓之助 : 草津溫泉に於ける2--3の

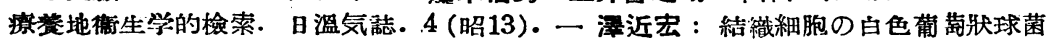
胞食実驗. 日組錄. 1(昭25)一閣正次：線粗系に及仕す溫泉入浴の作用. I. 强酸性 泉. 解剖誌. 20 (昭17a). 一 II. 良酸性泉と類中性泉. 解剖誌. 20 (昭17b). 一 VI. 人工硫黄泉. 日溫気誌. 10 (昭19). 一 Sluiter, E: The Production of hydrogen sulphide by animal tissues. Biochem. J. 24 (1930).

\section{附圆の說明}

線組系諸細胞の轉化.上牛は中性赤にての超生染像,一下牛は固定薄膜標本に於ける 铁へテティン染色像. Fbc 線維細胞, Fbhsc 線粗球, $M n c$ 單核球, $a m F b c$ アメー 六㩐線維細胞, $H s c$ 組織球. 


\section{關論文附圖}
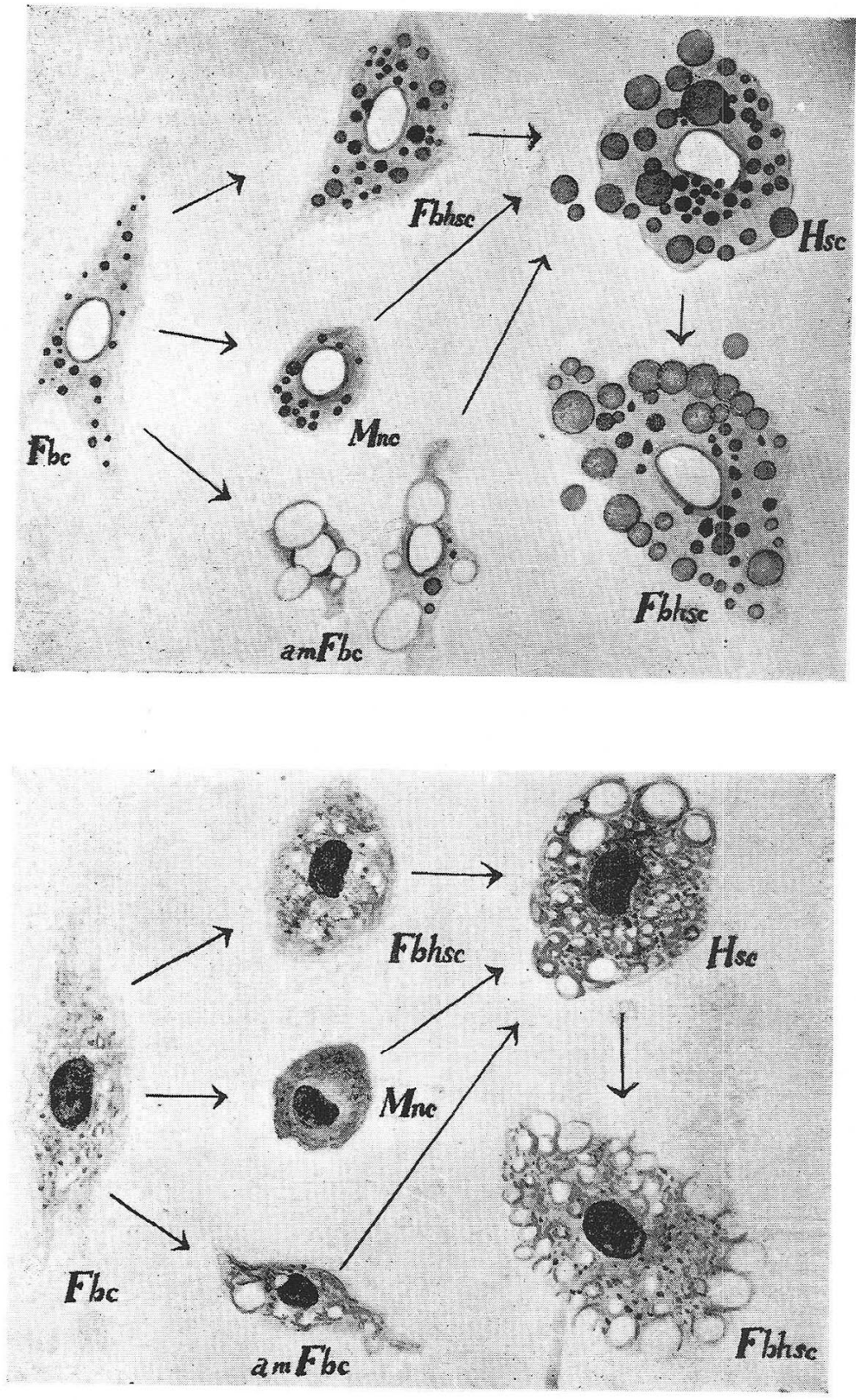